\title{
The Effect of Applying E-Filling Applications Towards Personal Taxpayer Compliance in Reporting Annual Tax Returning (SPT) in Bengkalis State Polytechnic Indonesia
}

\section{Suharyono ${ }^{1}$}

\section{ARTICLE INFO \\ Submitted : 11.06 .2018 \\ Revised : 13.07.2018 \\ Accepted : 19.07.2018 \\ Available : 30.07 .2018 \\ JEL classification: $\mathrm{H} 26, \mathrm{H} 29$, H83, L89 \\ Keywords: \\ Electronic, Filling, Compliance, Taxpayer, Individual}

\begin{abstract}
A B S T R A C T
Tax reform conducted by the Directorate General of Taxes, Ministry of Finance by providing more efficient service facilities to taxpayers in fulfilling taxation obligations through the modernization of tax applications that is tax reporting using an e-filling system. The purpose of this study is to determine the effect of applying e-filling application to the compliance of individual taxpayers in reporting annual Tax returning SPT notification. The objects of this research are lecturers and employees at Bengkalis State Polytechnic. Types of data used in this study are primary and secondary data. Data analysis using linear regression. The result of this research is e-filling application can improve personal taxpayer compliance in reporting annually notification letter easily, fast, effective and efficient as well as maintained the confidentiality of taxation data.
\end{abstract}

\section{Introduction}

\subsection{Background}

Tax is the largest revenue source in the State Budget (APBN). Taxes are dynamic and follow the development of the life of the country and its people. The demand for increased state revenues is also not free from the reform of the policy of the ministry of finance, especially in the field of taxation in the hope that taxes levied can be maximized.

In the era of increasingly advanced technology, especially in the field of electronics, giving positive impact to offices that require fast, precise and practical service. This fosters reforms for the Directorate General of Taxes under the auspices of

\footnotetext{
${ }^{1}$ (https://orcid.org/0000-0001-5820-9219), Program Studi D4 Akuntansi Keuangan Publik, Indonesia, suharyono@polbeng.ac.id
} 
Suharyono (2018). "The Effect of Applying E-Filling Applications Towards Personal Taxpayer Compliance in Reporting Annual Tax Returning (SPT) in Bengkalis State Polytechnic Indonesia", International Journal of Public Finance, Vol.3, No.1, pp. 47-62.

the Ministry of Finance to renew the application of taxation. One form of renewal by the Directorate General of Taxes is through the Information and Communication Technologies (ICT) system. According to Sutedjo (2002), ICT or information technology can be interpreted as a technology used to process data obtained from each element of the system into a form that is easily understood and is relevant knowledge in various ways to produce quality information.

Modernization of taxes occurred for the first time in 2005 when a new type of service to the Taxpayer was performed in the framework of the delivery of notification letters and the submission of annual tax return extension using electronic filling (efilling). E-Filling or Electronic Filing System is a system of reporting / submitting of taxes with the tax return (SPT) electronically done through the real-time on-line system so that will help 24 hours a day a week. With the expectation of the taxpayer can report his obligations effectively and efficiently.

General Provisions and Tax Procedures (UU KUP) no. 28 Article 1 of 2007 is submitted that the taxpayer is an individual or entity, including the payment of taxes, tax cutters, and tax collectors, which have taxation rights and obligations in accordance with the provisions of the legislation. While the Tax return (SPT) is a Letter by which the taxpayer is used to report the calculation and/or payment of taxes, tax objects, and/or assets and obligations under the provisions of tax laws. In the KUP SPT is divided into two namely SPT Masa and Annual SPT.

Tax compliance can be seen from how to fulfill all tax obligations. Tax compliance is an act of the taxpayer in the fulfillment of tax obligations in accordance with the provisions of applicable tax laws and regulations in a State. Tax compliance can be identified through taxpayer compliance in enrollment, compliance to remit SPT, compliance in calculating, and paying tax payable, compliance in reporting and payment of arrears.

Based on the above description the authors are interested to conduct research on the application of e-filling application titled Influence Application Implementation of e-filling Against Individual Taxpayer Compliance In Reporting Annual Tax Returns at Bengkalis State Polytechnic.

\section{Review of Literature}

\subsection{Previous Research}

Alla (2014) conducted a research entitled The System of Tax filing in Albania, "Efiling".The system of tax filing "e-filing" serves to help easily taxpayers to file electronically taxes. According to the article 65 of the law No.9920 Dt.19.05.2008 "The tax Procedures in the Republic of Albania", the tax documents will be disclosed only electronically since January 2010 for large taxpayers and from March 2010 for the 
Suharyono (2018). "The Effect of Applying E-Filling Applications Towards Personal Taxpayer Compliance in Reporting Annual Tax Returning (SPT) in Bengkalis State Polytechnic Indonesia", International Journal of Public Finance, Vol.3, No.1, pp. 47-62.

other taxpayers. After compiling and filing of the tax documents by taxpayers, administrators of IT must supervise the system of information to generate accurate financial reports and the tax inspectors should make the tax control of declarations. The purpose of this paper is to show, the importance of the e-filing system for taxpayers and tax administration and advantages and disadvantages of this system. Reasons for the implementation of this system are numerous, because of the facilities it offers; transparency system, saving time, avoiding the tax evasion, simplification of procedures, equal treatment of taxpayers by the tax authorities, etc.. This paper will show the main financial reports that generate the tax system, which is very essential to realize qualitative tax audit of taxpayers. According to this paper, I will give my conclusions and suggestions for the "e-filing" system.

Lim, Masrom, and Din (2014) in his research entitled The influence of eParticipation on e-Filing Participation: A Study of Citizen Adoption on e-Government Services. It is a global trend that many governments used web-based technologies to keep pace with the various changes arising from the socio-political and economic environment of the times. This paper asserts that the concept of e-government which was originally aimed to improve the efficiency of the government management system and more importantly to expand government revenue would eventually recast towards a participatory government, without which the survival of any institution cannot be guaranteed. The paper briefly reviewed major issues that might explain the e-Participation behavior. (They include: Information Quality, Systems Quality, User Satisfaction, Facilitating Condition, Performance Expectancy and Effort Expectancy). To this effect, Malaysia's e-Filing Taxation System (e-FTS) was studied due to the facts that despite incredible efforts put by the Malaysian government the actual citizen participation in the e-FTS is lagging. The Unified Theory of Acceptance and Use of Technology (UTAUT) Model was utilised to study the gap that exists between the expected and the actual citizen participation in Malaysia's e-Filing Taxation Systems (eFTS). The paper examines (i) the relationships between Information Quality and Systems Quality on User Satisfaction of the e-FTS; ii) the relationships between User Satisfaction on Performance and on Effort Expectancies of the e-FTS; iii) the effects of Performance and Effort Expectancies and Facilitating Condition (FC) on Behaviour Intention to Use (BIU) of the e-FTS; and finally (iv) effects of e-Participation on FC of the e-FTS. The results had indicated that e-Participation, Information Quality, and Systems Quality are significant indicators of taxpayers' intention to use the e-FTS. A confirmatory factor analysis (CFA) using AMOS was conducted to test the measurement model. In conclusion, Malaysian taxpayers were found to be rather pessimistic in using the new technology and e-Government services. Policy measures were forwarded which could be considered to close the gap between the high expectation and the reality of citizen adoption one Government services.

Azmi, Kamarulzaman, and Hamid (2012) in his research entitled Perceived Risk and the Adoption of Tax E-Filing. Many countries have introduced e-filing of tax returns 
Suharyono (2018). "The Effect of Applying E-Filling Applications Towards Personal Taxpayer Compliance in Reporting Annual Tax Returning (SPT) in Bengkalis State Polytechnic Indonesia", International Journal of Public Finance, Vol.3, No.1, pp. 47-62.

to help citizens fulfill their responsibilities toward the government. However, despite the presence of such e-services, researchers argue e-filing of taxes is not popular among the public, especially in developing countries like Malaysia, because of the high perceived risk associated with the service. The lack of coordinated efforts on the part of the service provider to counter individual perceptions of risk further discourages the adoption of the tax e-filing service. The paper uses the technology acceptance model to understand how perceived risk and its facets influence the adoption behavior of consumers. By analyzing data from 249 Malaysian taxpayers, the authors found that facets of perceived risk have a positive relationship with the adoption of tax e-filing whereas perceived ease of use of the system does not have a positive relationship with the adoption of tax e-filing. The model suggests that different risk facets may influence the adoption of tax e-filing and perceived usefulness of the system differently.

Agustiningsih (2016) conducted a research entitled The Effect of Implementation of E-Filing, Level of Understanding Taxation and Taxpayers Awareness of Taxpayer Compliance In KPP Pratama Yogyakarta. The results of this study show that the application of e-filing has a positive and significant impact on taxpayer compliance with the coefficient of determination 0.454. The level of understanding of taxation has a positive and significant impact on taxpayer compliance with the coefficient of determination 0.444 . Awareness of taxpayers has a positive and significant impact on taxpayer compliance with the coefficient value of determination 0.621. (4) Application of e-filing, the level of understanding taxation and awareness of taxpayers have a positive and significant impact on taxpayer compliance with $\mathrm{F}$ value count greater than $F$ table that is $59.820>3.94$.

Tambun and Witriyanto (2016) investigated Influence Taxpayer Awareness and Application of E-System against Taxpayer Compliance Levels with Risk Preference for Moderating Variable. Based on statistical test result: taxpayers' awareness has a positive and insignificant effect on taxpayer compliance level, e-system implementation has a positive and significant effect on taxpayer compliance level, risk preference has no significant effect on taxpayer awareness and implementation of esystem to taxpayer compliance level.

According to Abdul and Jeff's (2008) research entitled "The Compliance Cost of the Personal Income Taxation in Malaysia", estimates the income tax compliance costs, and measures possible noncompliance behavior, from a business managerial perspective in Malaysia. The findings reported in this paper are into the Malaysian small and medium enterprises (SMEs) under the income tax self-assessment system. The findings show that the SMEs are being compliant in terms of income reporting and accuracy in their deductions. The investigation into the relationship between the size of the tax compliance costs and likely compliance behavior indicates no statistical significance. Possible reasons for these findings are presented. 


\subsection{Tax Technology}

Tax technology is a system used by taxpayers to report compulsory donations to the state or government in respect of income, ownership, purchase price of goods, and so forth. The tax technology used in this study include Electronic Invoice Number, Electronic tax return, and E-Filing.

\section{E-NOFA (Electronic Invoice Number)}

According to Rizqiah (2012), E-NOFA (Electronic Invoice Number) Is a new system or application in tax invoice numbering, and also one form of modernization being intensified Directorate General of Taxes in order to prevent the use of fictitious invoices and facilitate in the supervision of the numbering tax invoice. The new policy made by the Directorate General of Taxes owed in PER-24 / PJ / 2012 concerning the form, size, procedure of filling in the information, notification procedures for making, the procedure for the correction or replacement, and the procedure for cancellation of E-NOFA tax invoice is a form of service improvement Directorate General of Taxes to the public, especially PKP through the control of the tax invoice serial number is the numbering of tax invoices that are no longer done manually by pkp but controlled by the Directorate General of Taxes.

\section{E-SPT (Tax ReturnElectronic)}

E-SPT is an application made by the DGT used by taxpayers to report tax return or the Notice to be more easily and do not spend a lot of paper. E-SPT is short for electronic tax return. E-SPT is one form of innovation from the Directorate General of Taxation. Because for decades the country's tax revenue management has been reported by Taxpayers manually using a lot of paper, but this can be minimized using paper through the use of E-SPT applications (www.pajak.go.id).

\section{SPT Considered Not to Be Delivered}

In Article 3 paragraph 7 of the Law on KUP stated that SPT is considered not submitted if:

1. SPT is not signed

2. SPT is not accompanied by information or documents in accordance with the Regulation of the Minister of Finance

3. The overpayment of SPT is passed within 3 years after the expiry of the taxable year, the taxable year and the taxable year, and the Taxpayer has been reprimanded in writing.

4. SPT is submitted after the Directorate General of Taxation to examine or issue SKP. If the SPT is deemed not to be submitted, the Directorate General of Tax shall notify the Taxpayer (Article 3 paragraph 7a of the KUP Law). SPT is considered as data taxation. 
Suharyono (2018). "The Effect of Applying E-Filling Applications Towards Personal Taxpayer Compliance in Reporting Annual Tax Returning (SPT) in Bengkalis State Polytechnic Indonesia", International Journal of Public Finance, Vol.3, No.1, pp. 47-62.

\section{Sanctions for Not Spreading SPT}

Sanctions for taxpayers who do not submit SPT, in the form of administrative sanctions or criminal sanctions. Administrative sanction in the form of fine as regulated in Article 7 of the Law of KUP shall be an increase as regulated in Article 13 paragraph 3 of the KUP Law. Criminal sanctions are in the form of confinement for a criminal act of omission as stipulated in Article 38 of KUP Law or prison on the intentional criminal act as regulated in Article 39 of KUP Law.

\section{Warning Letter on SPT not submitted.}

If the SPT is not submitted within the prescribed time limit or the deadline for extending the Annual Tax Return, a Warrant Letter (Article 3 Paragraph 5a of the KUP Law) may be issued. Issuance of the warning letter is a form of guidance to the Taxpayer concerned with administrative sanctions in the form of an increase as referred to in Article 13 paragraph 1 letter $b$ and article 13 paragraph 3 of the Law on KUP.

\section{Administrative sanction in the form of the fine.}

Article 7 Paragraph (1) of the KUP Law stipulates that if the SPT is not submitted within the period of time or the deadline for extension of the delivery of SPT, may be liable to administrative sanctions in the form of a fine of Rp. 500,000.00 (five hundred thousand rupiahs) for the VAT period, Rp. 100,000.00 one hundred thousand rupiahs) for other SPT period, Rp. 1,000,000.00 (one million rupiahs) for the annual tax return of the corporate taxpayers of Rp. 100,000.00 (one hundred thousand rupiahs) for the Annual Income Tax Income Taxpayer.

\section{E-Filing (Electronic Filing)}

E-Filing is one way of delivering tax reporting through electronic media Online \& Real Time to DJP and can be used by all corporate and Individual Taxpayers throughout Indonesia. In general, the submission of SPT or the submission of the Annual SPT Renewal Notice electronically through e-filing is regulated through the Directorate General of Tax Regulation No. PER-26 / PJ / 2012 on the procedure of receipt and processing of annual notification letters. Specifically, the submission of SPT or the submission of the Annual Renewal of SPT Renewal by electronic e-filing on the Directorate General of Taxes website shall be regulated through the Directorate General of Taxes Regulation No. PER39 / PJ / 2011 on the Procedure of Submitting an Annual Tax Return for Individual Taxpayer by Using Form 1770S or 1770SS E-filing Through the Website of the Directorate General of Taxation (www.pajak.go.id)

\subsection{Electronic Filing Procedure}

A procedure of using E-Filing as an online tax application As for the steps that must be done by the taxpayer to use e-filing: 
The first step is to apply

1. Apply in writing to the head of the tax service office where the taxpayer is registered in accordance with the sample application letter, by attaching the following data:

a. Photocopy of Taxpayer Identification Number card or Certificate.

b. In the case of a taxable entrepreneur accompanied by a photocopy of a letter of entrustment of a taxable entrepreneur.

2. The application as mentioned above may be approved if:

a. The address listed on the application of the address in the taxpayer database at the Director General of Taxes.

b. For taxpayers who have the obligation to submit notices and have submitted an annual personal income tax or corporate income tax for the most recent fiscal year.

c. Annual notice of income tax article 21 for the last fiscal year.

d. Notice of the value added tax for the last 6 tax periods.

3. Head of Tax Service Office shall give a decision on the application submitted by the taxpayer to be able to obtain electronic filing.

4. Head of Tax Service Office shall decide on the application filed by the taxpayer to be able to obtain Electronic Filing Identification Number (e-FIN) no later than 2 working days since the application is received completely.

\section{Second Step: Registration}

1. Taxpayers who have received an Electronic Filing Identification Number (eFIN) from the tax office register through the website.

2. After the taxpayer enrolls, the tax service will provide:

a. User ID and Password.

b. The e-SPT application with its usage instructions and other information, subject to the type of tax required.

c. Digital certificate obtained from the Directorate General of Taxes based on the Electronic Filing Identification Number that has been registered by the taxpayer.

3. Digital Certificate will be installed automatically into a computer that can be used by taxpayers to do registration, for example, function to:

a. Security by printing e-SPT data.

b. Authentication of the sender of e-SPT data. 
c. Ensure the integrity of e-SPT data.

d. Prevent denial.

The third step is E-Filing

Tax can prepare and fill out the SPT off-line through the e-SPT application that has been given. After the data is complete, the e-filing report submission is done online through the website https://efiling.layananpajak.com/registrasiwp.

\subsection{Benefits of Electronic Filing}

The benefits of E-filing for taxpayers are:

1. Reporting or submitting SPT can be done at any time without knowing the day off.

2. Data input error can be easily revised when filling data on the e-SPT form, without having to delete or replace SPT sheet paper.

3. Reduce the cost of printing SPT stuffing sheet 4) Simplify the process, where SPT reporting is not necessary by visiting and following the queue at the Tax Office.

4. Confirmation from the Directorate General of Taxes on receipt of the tax report can be obtained on the spot after the data sent has been correct and complete.

5. Centralized VAT tax submission for taxpayers of agencies that have several branch offices can be done so as to facilitate the consolidation of tax reporting between branches.

\subsection{Advantages of Electronic Filing}

The benefits that taxpayers can feel in using e-filing are:

1. Delivery of SPT that can be done quickly, safely, and anytime.

2. Cheap, and not charged at the time of SPT reporting.

3. A calculation is done precisely because using the computer system.

4. Ease in filling the SPT due to filling SPT in the form of wizard.

5. Data submitted by the Taxpayer is always complete because there is a validation of SPT filling.

6. Environmentally friendly by reducing paper usage.

Supplementary Documents (photocopy of Form 1721 A1 / A2 or proof of income tax, SSP of Third Sheet of Income Tax Article 29, Special Power of Attorney, calculation of Income Tax owed to the Taxpayer of the Marriage and / or Own NPWP, 
Suharyono (2018). "The Effect of Applying E-Filling Applications Towards Personal Taxpayer Compliance in Reporting Annual Tax Returning (SPT) in Bengkalis State Polytechnic Indonesia", International Journal of Public Finance, Vol.3, No.1, pp. 47-62.

Copy of Zakat Payment Proof) sent again unless requested by the Tax Office through Account Representative.

\section{Research Methods}

\subsection{The Design of Research}

The scope in this study the authors reviewed in the field of e-filling application system focused on the problem of the application of electronic filling (e-filling) to the compliance of individual taxpayers in reporting annual tax return to lecturers and employees of Bengkalis State Polytechnic has been registered as an individual taxpayer.

\subsection{Research Setting}

The research location used as research object is Bengkalis State Polytechnic located in Jalan Bathin Alam Desa Sei Alam Bengkalis Riau. The reason the authors do the research because as follows:

1. The e-filling Application System is eligible for research.

2. Lecturers and employees in Bengkalis State Polytechnic environments who have been registered to be individual taxpayers are open to providing information.

\subsection{Data Types and Data Sources}

The types of data to be analyzed are as follows: The type of data used in this study as follows:

\section{Quantitative Data}

Quantitative data used in this study is the number of lecturers and employees of Bengkalis State Polytechnic.

\section{Qualitative Data}

The qualitative data used in this study are data on a general description of Bengkalis State Polytechnic, location, e-filling application system, annual text return which has been reported and the result of a questionnaire.

The data source used by the writer in evaluating to get research conclusion is primary data, that is data about the number of lecturer and employee, general description of Bengkalis State Polytechnic, location, e-filling application system, Annual SPT which have been reported and questionnaire result. 


\subsection{Data Collection Technique}

1. Interview

Interviews were conducted with lecturers, staff, and students to obtain data on the e-filling application system.

\section{Documentation}

From the documentation obtained data about the number of lecturers and employees, the general picture Bengkalis State Polytechnic, location and SPT Annual has been reported.

\section{Questionnaire}

This questionnaire is intended to obtain data on the application of e-filling application to the compliance of individual taxpayers in reporting Annual Tax Return.

\subsection{Identify Variables}

In this study the variables studied consist of two kinds, namely:

1. E-filling application

2. Taxpayer Compliance

\subsection{Operational Definition of Variables}

1. The e-filling application shall be an Annual or Annual Tax Return in the form of electronic forms in computer media, where the delivery shall be made electronically in the form of digital data transferred or forwarded to the Directorate General of Taxes through an Application Service Provider (ASP) appointed by the Director General of Taxes by an online process. (Decree of the Director General of Taxation Number: KEP88 / PJ. / 2004 dated May 14, 2004 jo KEP05 / PJ. / 2005 dated January 12, 2005).

2. Taxpayer Compliance is a condition where the taxpayer meets all tax obligations and exercising his taxation rights (Rahman, 2010).

\subsection{Variable Indicators}

The independent variable or independent variable $(X)$ is the variable that influences or becomes the cause of the change in the dependent variable. While the dependent variable or dependent variable $(\mathrm{Y})$ is the variable that is affected or become a result due to the change of the independent variable. The related indicators in these variables are:

E-filling Application Indicators, as follows:

1. Ease of operating the e-filling application. 
Suharyono (2018). "The Effect of Applying E-Filling Applications Towards Personal Taxpayer Compliance in Reporting Annual Tax Returning (SPT) in Bengkalis State Polytechnic Indonesia", International Journal of Public Finance, Vol.3, No.1, pp. 47-62.

2. Ease of reporting Annual Tax Return using e-filling application.

3. The accuracy and speed in reporting the Annual Tax Return using e-filling application are more effective.

4. The Efficiency of cost, time and effort in reporting Annual Tax Return by applying e-filling so that it is more economical and practical.

Taxpayer Compliance Indicators, as follows:

1. Compliance to refund SPT is in the form of timely in paying taxes, and the number of tax payment places that can facilitate in paying taxes.

2. Compliance in calculating, calculating, and paying taxes owed in the form of performing calculations correctly, the application of strict sanctions, and tax audits by tax officials.

3. Compliance in Reporting and know the tax reporting deadline.

4. Compliance in reporting and payment of arrears, namely in the form of tax arrears that increase the tax burden and the willingness of taxpayers in paying tax arrears.

\subsection{Variable Measurement Method}

The population in this study is 260 respondents taken random samples from lecturers and employees who have registered to taxpayer person. To facilitate the researchers determine the respondents with the following criteria: respondents are lecturers and employees who have been NPWP and report annual tax returns 20122017. The measurement scale used in classifying variables measured so that no errors in determining the data analysis is Likert scale. Likert scale is used to measure attitudes, opinions, and perceptions of a person or group of social events or phenomena (Sugiyono, 2008).

\subsection{Hypothesis Model}

The Hypothesis is a temporary answer to the formulation of research problems (Sugiyono, 2008). Based on the above conceptual model drawings can be proposed a hypothetical model as follows:

Figure 1. Hypothesis Framework

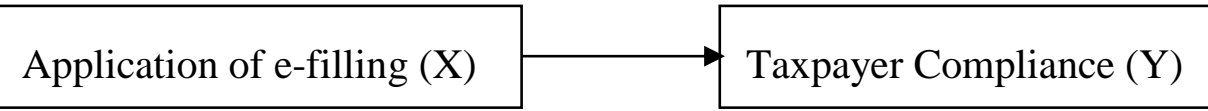




\subsection{Data Analysis Technique}

Data analysis methods used to answer the hypothesis is the analysis of description and simple linear regression analysis. The reason for using this regression model is to know the relation between the independent variable that is an application of e-filling $(\mathrm{X})$, to the dependent variable that is taxpayer obedience $(\mathrm{Y})$. The model equation of linear regression analysis is as follows:

$$
\mathbf{Y}=\mathbf{a}+\mathbf{b x}
$$

Information:

Y: Taxpayer compliance

a: The constant of the regression equation

bx: Regression coefficient of variable X (Application e-filling)

The steps are as follows:

1. The questionnaire analysis has been completed by 100 respondents related to the application of the e-filling application to the taxpayer compliance of the individual in reporting the annual notification letter (annual tax return). The results of the questionnaire responses were made distributed tables.

2. Determine the score of respondents' answers with the provisions of predefined scores

3. Sums up the score of answers obtained from each respondent

Incorporate the score into SPSS program version 22.0.

\section{Research Result}

\subsection{Descriptive Analysis}

The result of the descriptive analysis is the simplification of respondent data in the form of research respondents. The results of the descriptive analysis can be seen in the following table.

Table 1: Respondent

\begin{tabular}{|c|c|c|c|c|}
\hline \multirow{2}{*}{ Job Title } & \multicolumn{3}{|c|}{ Type of Employee } & \multirow{2}{*}{ Total } \\
\cline { 2 - 5 } & CPNS/PNS & $\begin{array}{c}\text { Employee } \\
\text { Non PNS }\end{array}$ & $\begin{array}{c}\text { Employee Not } \\
\text { Permanent }\end{array}$ & \\
\hline Lecturer & 54 & 25 & 45 & 124 \\
\hline Employee & 13 & 30 & 93 & 136 \\
\hline \multicolumn{4}{|r}{ Jumlah } & 260 \\
\hline
\end{tabular}


Suharyono (2018). "The Effect of Applying E-Filling Applications Towards Personal Taxpayer Compliance in Reporting Annual Tax Returning (SPT) in Bengkalis State Polytechnic Indonesia", International Journal of Public Finance, Vol.3, No.1, pp. 47-62.

Bengkalis State Polytechnic has 260 employees as both a lecturer and as an education staff.

\subsection{Simple Linear Regression Analysis}

From answer questionnaires that have been filled by respondents and have been processed with the help of SPSS Version 22.0 then the results of calculation of simple linear regression analysis on the research on the effect of the application of efilling application on the compliance of individual taxpayers in reporting annual notification (annual SPT), as follows:

$$
Y=3.653+1.012 X
$$

Information :

Y: Taxpayer compliance

$X$ : Application of e-filling

In the equation can be seen the independent variables in this study have a positive effect on the dependent variable.

\subsection{Hypothesis Testing the Coefficient of Determinant (R2)}

Based on the results of determination coefficient test of magnitude $R$ in this study is 0.914 which indicates that there is a positive relationship between the perceptions of an e-filling application on the compliance of individual taxpayers in reporting the annual tax return. The value of $\mathrm{R}$ square which is the value of R2 of 0.914 $=91.4 \%$ means that the perception variable of e-filling application affects the taxpayer's compliance in reporting the annual tax return. The remaining $8.6 \%$ comes from other variables.

Based on the results of research that has been done can be seen that the independent variable is the application of e-filling affects the dependent variable that is taxpayer compliance in Bengkalis State Polytechnic of $91.4 \%$ with indicator of obedient taxpayer reflected from the compliance to deposit the SPT is in the form of timely in pay taxes, and know the number of tax-payments that can facilitate paying taxes, compliance in calculating, calculating, and paying taxes owed in the form of calculations correctly, the application of strict sanctions, and tax audits by tax officials, compliance in reporting and knowing deadline of tax reporting, compliance in reporting and payment of arrears, in the form of tax arrears that increase the tax burden and the willingness of taxpayers in paying tax arrears and knowing the number of places to report taxes (either manually / dropbox or e-filling) that can facilitate in reporting taxes and there is another factor of $8.4 \%$ that affects the dependent variable outside the variables studied. 
Suharyono (2018). "The Effect of Applying E-Filling Applications Towards Personal Taxpayer Compliance in Reporting Annual Tax Returning (SPT) in Bengkalis State Polytechnic Indonesia", International Journal of Public Finance, Vol.3, No.1, pp. 47-62.

\subsection{Influence of Application Implementation of e-filling Against Individual Taxpayer Compliance In Reporting Annual Tax Return.}

Based on the results of hypothesis testing using t-test shows that the application of e-filling is $0.04<0.05$. The results of this test show that the application of e-filling effect partially to the compliance of individual taxpayers. The results of this study indicate that the application of e-filling increases the compliance of individual taxpayers in reporting the annual tax return.

Application of e-filling application in the taxation system that embraces the self-assessment system in Indonesia demands the taxpayer to carry out his own tax obligations. The e-filling application is a computer application system created by the Directorate General of Tax (DGT) which is intended for taxpayers in reporting the Annual Tax Return. Annual Reporting of SPT by using e-filling application is considered more efficient than using manual SPT, so using e-filling taxpayer can easily carry out tax obligations. The advantages possessed by e-filling applications using computer and internet systems so that taxpayers can properly organize data taxation systematically, and quickly and awake the confidentiality of tax data has been reported. Another advantage in reporting the Annual Tax Return using e-filling taxpayers no longer need to queue at the tax office and where reported other annual SPT (dropbox).

\section{Conclusions and Suggestions}

\subsection{Conclusion}

From the results of research that has been done in Bengkalis State Polytechnic, it can be concluded as follows:

1. Hypothesis test results show that e-filling application variables have a positive and significant influence on the dependent variable or taxpayer compliance variable. The results indicate that the application of e-filling increases the compliance of individual taxpayers in reporting the annual tax return.

2. Determination coefficient test results show that $91.4 \%$ of the existence of efilling applications affect the compliance of individual taxpayers in reporting the annual tax return, while $8.6 \%$ influenced by other variables.

\subsection{Suggestion}

This research is expected to provide benefits for further researchers related to application implementation. Suggestions for further researchers are:

1. Given the e-filling application is very influential on taxpayer compliance this is in order to get special attention by the DJP to continue to innovate. Preferably, the DGT makes additions to the application service provider/application service provider (ASP) so that the e-filling can be used taxpayer evenly. 
Suharyono (2018). "The Effect of Applying E-Filling Applications Towards Personal Taxpayer Compliance in Reporting Annual Tax Returning (SPT) in Bengkalis State Polytechnic Indonesia", International Journal of Public Finance, Vol.3, No.1, pp. 47-62.

2. The next research the researcher can develop the research variables in order to know the improvement of personal taxpayer compliance in reporting the Annual Tax Return.

Expand the population or location of the study.

\section{References}

Abdul Jabbar Hijattulah dan Jeff Pope, 2008, Exploring The Relationship Between Tax Compliance Costs and Compliance Issues in Malaysia, Journal of Applied Law and Policy.

Agustiningsih, Wulandari. 2016. Pengaruh Penerapan E-Filing, Tingkat Pemahaman Perpajakan Dan Kesadaran Wajib Pajak Terhadap Kepatuhan Wajib Pajak di KPP Pratama Yogyakarta. Jurnal Nominal, Volume 5, Nomor 2, Halaman: 107-122.

Alla, Mikel. 2014. conducted a research entitled The System of Tax filing in Albania, "Efiling". International Journal of Science and Technology, Volume 3 No. 9, September 2014. pp. 501-507

Azmi, Anna A.C., Kamarulzaman, Yusniza and Hamid, Nor H.A. 2012. Perceived Risk and the Adoption of Tax E-Filing. World Applied Sciences Journal, Vol. 20, No. 4, pp. 532-539.

Bremen, A. Jason and Morgan, S. Belinda. 2004. States Adopt a Profitable 'Carrot and Stick' Approach to Tax Amnesty. Journal of Multistate Taxation and Incentives, Jul 2004, pp.1-7.

Dijen. (2014), Informasi E-Filling Melalui Penyedia Jasa Aplikasi Atau Aplication Service Provider (ASP). Diakses pada 07 Februari 2016 dari http://www.pajak.go.id

Efferin, Sujoko. Stevanus Hadi Darmaji dan Yuliawati Tan (2004), Metode Penelitian Untuk Akuntansi, Malang: Bayumedia Publising.

Lim, Ai Ling, Masrom, Maslin and Din, Sabariyah. 2014. The influence of e-Participation on e-Filing Participation: A Study of Citizen Adoption on e-Government Services. International Journal of Engineering Science and Innovative Technology (IJESIT), Volume 3, Issue 5, pp. 251-260.

Luitel, S. Hary and Sobel, S. Russell. 2005. The Revenue Impact Of Repeated Tax Amnesties. Working Paper. http://www.papers.ssrn.com, di download tanggal 14 Maret 2009, pp1-37.

Mardiasmo, (2009). Perpajakan. Edisi Revisi, Yogyakarta: Andi Offset.

Muljono, Djoko dan Baruni Wicaksono.(2009). Akuntansi Pajak Lanjutan. Yogyakarta: Andi Offset. 
Suharyono (2018). "The Effect of Applying E-Filling Applications Towards Personal Taxpayer Compliance in Reporting Annual Tax Returning (SPT) in Bengkalis State Polytechnic Indonesia", International Journal of Public Finance, Vol.3, No.1, pp. 47-62.

Purwono, Herry. (2010). Dasar-Dasar Perpajakan dan Akuntansi Pajak. Yogyakarta: Erlangga.

Rahman, Abdul. (2010), Panduan Pelaksanaa Administrasi Perpajakan. Bandung: Penerbit Nuansa.

Republik Indonesia, Undang-Undang Nomor 28 Tahun 2007 tentang Perubahan Ketiga atas UndangUndang Nomor 6 Tahun 1983 tentang Ketentuan Umum dan Tata CaraPerpajakkan.

Resmi, Siti. (2014). Perpajakan Teori dan Kasus. Jakarta: Salemba Empat.

Risky, Dianita. (2015), Analisis FaktorFaktor Yang Mempengaruhi Intensitas Perilaku Dalam Penggunaan Sistem E-Filling. Jurnal Administrasi Bisnis - Perpajakan (JAB) Vol. 6 No. 12015

Ritsema, Christina and Thomas, Deborah and Ferrier, Gary. 2003. Economic and behavioral Determinants of tax compliance: Evidence from the 1997 Arkansas tax penalty amnesty program. Presented at the 2003 IRS Research Conference. Working Paper, http://www.papers.ssrn.com di download tanggal 14 Maret 2009, pp 1-27

Suandy, Erly (2011). Perencanaan Pajak, Edisi Keempat, Jakarta: Salemba Empat.

Supramono dan Theresia Woro Damayanti. (2010). Perpajakan Indonesia Mekanisme dan Perhitungan, Yogyakarta: Andi Offset.

Tambun, Sihar. 2016. Pengaruh Kesadaran Wajib Pajak Dan Penerapan E-System Terhadap Tingkat Kepatuhan Wajib Pajak Dengan Preferensi Resiko Sebagai Variabel Moderating. Media Akuntansi Perpajakan, Vol. 1, No. 2, Halaman: 8694.

Waluyo (2013), Perpajakan Indonesia, Edisi Kesebelas, Jakarta: Salemba Empat.

Zuhdi, Firdaus Aprian. 2015. Pengaruh Penerapan E-Spt Dan Pengetahuan Perpajakan Terhadap Kepatuhan Wajib Pajak (Studi Pada Pengusaha Kena Pajak yang terdaftar di KPP Pratama Singosari). Jurnal Perpajakan (JEJAK) Vol. 7 No. 1. 2015 